\title{
A Cross-Sectional Study of Nemaline Myopathy
}

Kimberly Amburgey, MS, Meryl Acker, MSc, Samia Saeed, BSc, Reshma Amin, MD, Alan H. Beggs, PhD, Carsten G. Bönnemann, MD, Michael Brudno, PhD, Andrei Constantinescu, MD, Jahannaz Dastgir, MD, Mamadou Diallo, MS, MS, Casie A. Genetti, MS, Michael Glueck, PhD, Stacy Hewson, MSc, Courtney Hum, MSc, Minal S. Jain, PT, DSc, Michael W. Lawlor, MD, PhD, Oscar H. Meyer, MD, Leslie Nelson, PT, PhD, Nicole Sultanum, MSc, Faiza Syed, RRT, Tuyen Tran, RRT, Ching H. Wang, MD, and James J. Dowling, MD, PhD

Neurology ${ }^{\circledR}$ 2021;96:e1425-e1436. doi:10.1212/WNL.0000000000011458

\section{Abstract}

\section{Objective}

Nemaline myopathy (NM) is a rare neuromuscular condition with clinical and genetic heterogeneity. To establish disease natural history, we performed a cross-sectional study of NM, complemented by longitudinal assessment and exploration of pilot outcome measures.

\section{Methods}

Fifty-seven individuals with NM were recruited at 2 family workshops, including 16 examined at both time points. Participants were evaluated by clinical history and physical examination. Functional outcome measures included the Motor Function Measure (MFM), pulmonary function tests (PFTs), myometry, goniometry, and bulbar assessments.

\section{Results}

The most common clinical classification was typical congenital (54\%), whereas $42 \%$ had more severe presentations. Fifty-eight percent of individuals needed mechanical support, with $26 \%$ requiring wheelchair, tracheostomy, and feeding tube. The MFM scale was performed in 44 of 57 participants and showed reduced scores in most with little floor/ceiling effect. Of the 27 individuals completing PFTs, abnormal values were observed in 65\%. Last, bulbar function was abnormal in all patients examined, as determined with a novel outcome measure. Genotypes included mutations in ACTA1 (18), NEB (20), and TPM2 (2). Seventeen individuals were genetically unresolved. Patients with pathogenic ACTA1 and NEB variants were largely similar in clinical phenotype. Patients without genetic resolution had more severe disease.

\section{Conclusion}

We present a comprehensive cross-sectional study of NM. Our data identify significant disabilities and support a relatively stable disease course. We identify a need for further diagnostic investigation for the genetically unresolved group. MFM, PFTs, and the slurp test were identified as promising outcome measures for future clinical trials.

\author{
Correspondence \\ Dr. Dowling \\ james.dowling@sickkids.ca
}

MORE ONLINE

๑ CME Course

NPub.org/cmelist

From the Division of Neurology (K.A.), Genetics and Genome Biology (K.A., M.A., J.J.D., M.B., N.S.), Division of Respiratory Medicine (R.A., F.S., T.T.), Centre for Computational Medicine (M.B., N.S.), Division of Emergency Medicine (M.D.), and Division of Clinical and Metabolic Genetics (S.H.), Hospital for Sick Children; Princess Margaret Hospital (S.S.), Department of Medical Oncology and Hematology; University of Toronto (R.A.), Ontario, Canada; The Manton Center for Orphan Disease Research (A.H.B., C.A.G.), Division of Genetics and Genomics, Boston Children's Hospital, Harvard Medical School, MA; National Institute of Neurological Disorders and Stroke (C.G.B.), Neuromuscular and Neurogenetic Disorders of Childhood Section, and Clinical Research Center (M.S.J.), Rehabilitation Medicine Department, NIH, Bethesda, MD; Department of Computer Science (M.B., M.G., N.S.), University of Toronto, Ontario, Canada; Columbia University Irving Medical Center (A.C.), Division of Pediatric Pulmonology, New York, NY; Goryeb Children's Hospital (I.D.), Department of Pediatric Neurology, Morristown, NJ; Mount Sinai Hospital (C.H.), Prenatal Diagnosis and Medical Genetics, Toronto, Ontario, Canada; Medical College of Wisconsin (M.W.L.), Department of Pathology and Laboratory Medicine, Milwaukee; Children's Hospital of Philadelphia (O.H.M.), Division of Pulmonology, PA; UT Southwestern Medical Center (L.N.), Department of Physical Therapy, Dallas, TX; and Driscoll Children's Hospital (C.H.W.), Division of Neurology, Texas A\&M University, Corpus Christi.

Go to Neurology.org/N for full disclosures. Funding information and disclosures deemed relevant by the authors, if any, are provided at the end of the article. 


\section{Glossary}

FVC $=$ forced vital capacity; MFM = Motor Function Measure MRC = Medical Research Council; NM = nemaline myopathy; PFT $=$ pulmonary function test.

Nemaline myopathy (NM) is characterized by congenital onset bulbar and extremity weakness and hypotonia. ${ }^{1}$ The condition was historically defined by the muscle biopsy finding of nemaline rods. ${ }^{1}$ Mutations in 12 genes have been associated with $\mathrm{NM}$. The most common genotypes are $N E B^{2,3}$ and $A C T A 1^{4,5}$ Other causes include mutations in TPM $2,{ }^{6}$ TPM $3,{ }^{7,8}$ KBTBD 13, ${ }^{9}$ CFL 2, ${ }^{10}$ KLHL40, ${ }^{11}$ KLHL41, ${ }^{12}$ LMOD $3,{ }^{13}$ MYPN $,{ }^{14}{ }^{T N N T 1},{ }^{15,16}$ and TNNT3. ${ }^{17}$ At present, there are no proven disease-modifying therapies for NM.

There have been several case-cohort studies and genotypephenotype examinations. ${ }^{3,18-21}$ Ryan et al. ${ }^{18}$ categorized patients with NM into 5 subtypes: severe congenital, intermediate congenital, Amish, typical congenital, and later onset. ${ }^{3,18}$ The typical congenital form is most common and is considered nonprogressive and non-life limiting. ${ }^{22}$ This group also identified several atypical features, including congenital fractures, progressive distal weakness, cardiac abnormalities, and CNS findings. Few genotype-phenotype correlations have been identified. Wallgren-Pettersson et al. ${ }^{3}$ reported that patients with NEB mutations had a milder phenotype. Maggi et al. ${ }^{20}$ found that more patients with ACTA1 mutations required a feeding tube, while Colombo et al. ${ }^{21}$ identified similar proportions of patients with both genotypes who required respiratory and feeding supports.

Detailed natural history is needed to optimize current clinical care and to identify potential outcome measures for future clinical trials. With this in mind, we evaluated disease features and quantitative measures in a cohort of 57 individuals with NM. We provide an in-depth cross-sectional study of NM, plus longitudinal assessment in a subset of cases.

\section{Methods}

Our cohort included male $(\mathrm{n}=27)$ and female $(\mathrm{n}=30)$ participants 1 to 57 years of age (the age at study entry was unknown for 1 participant). The diagnosis of NM was based on genetic confirmation of ACTA1, NEB, or TPM2 pathogenic variants $(n=40)$ or a clinical diagnosis of NM based on a muscle biopsy consistent with the presence of nemaline rods $(n=16)$ or clinical features of NM with a family history of nemaline rods on muscle biopsy $(n=1)$. Of note, 33 of 40 of the genetically established cases also had muscle biopsy, and all biopsies contained nemaline rods.

Participants were recruited at NM family conferences hosted by A Foundation Building Strength in 2009 and 2016 (White Plains, NY). A subset of participants attended both conferences, during which longitudinal data were collected $(n=16)$.
The remainder of individuals participated at 1 time point exclusively, either $2009(\mathrm{n}=16)$ or $2016(\mathrm{n}=25)$. Subjects participating exclusively in 2009 were not recontacted; therefore, the study team could not verify current living status. At study entry, 1 deceased individual was enrolled. Ethnicity was captured for 41 participants (32 White/Caucasian, 3 Native American, 1 Middle Eastern, 4 Hispanic, 1 Asian, 1 Black/ African American, and 8 Ashkenazi Jewish individuals); 9 of 41 reported multiple ethnicities.

\section{Standard Protocol Approvals, Registrations, and Patient Consents}

Written informed consent was obtained according to the Declaration of Helsinki from all participants or a parent/legal guardian. The cross-sectional study was approved by the Institutional Review Board of Boston Children's Hospital (No. M09-08-0403, 2009) and the Research Ethics Board at the Hospital for Sick Children (No. 1000053925, 2016). All participants were deidentified and provided with unique study identifiers.

\section{Study Measures}

Cross-sectional data were collected on written source documentation (2009) or uploaded directly into 2 electronic systems, REDCap and PhenoTips (2016). At the family conferences, the following measures were assessed: medical questionnaire (including pedigree, pregnancy, birth, developmental and medical histories), physical examination, motor assessments (Gowers maneuver, 10-m run test, stair climb test, Motor Function Measure [MFM] 20 or $32,{ }^{23}$ and myometry), goniometry, and pulmonary function tests (PFTs).

Timed Gowers measured the time taken to rise from lying on the floor to standing. Reference values for the timed Gowers were for individuals rising from seated on the floor to standing and were calculated from an average of the mean values from 2 to 12 years of age. ${ }^{24}$ Reference values for the 10 -m run test for healthy children 2 to 12 years of age (range $4.63-7.95$ seconds) were included. ${ }^{24}$ The MFM20 was used in 2009, and the MFM32 was used in 2016, with MFM20 values extracted from the larger MFM32 dataset to facilitate comparison. The MFM reflects testing in 3 domains: standing and transfers (domain 1), axial and proximal motor function (domain 2), and distal motor function (domain 3). Direct muscle strength was measured with Medical Research Council (MRC) grading. Measure of facial and trunk muscle strength is not performed with MRC grading. Myometry was performed to quantify muscle strength at the elbow, knee, and hip joints. Normalized myometry values were defined by the study physiotherapist (calculated from weight, sex, age, and handedness). Goniometry scores were measured for the elbows, 
knees, and ankles. Categories were defined by the study physiotherapist (grade 0 [no contracture/hyperflexibility]grade 4 [most severe contracture]). Reference values for PFTs were included for forced vital capacity (FVC), ${ }^{25}$ maximal inspiratory pressure, ${ }^{26}$ and peak cough flow. ${ }^{27}$ Participants were excluded from FVC percent predicted calculation if height and weight were not captured or if they were unable to perform the assessment.

Bulbar function was assessed via 2 scales, the Drooling Rating $\mathrm{Scale}^{28}$ and the Drooling Impact Scale, ${ }^{29}$ and 1 quantitative test. For the Drooling Rating Scale, drooling severity and frequency are ranked on a scale of 1 (severity: dry, frequency: never) to 5 (severity: profuse, frequency: constant). The Drooling Impact Scale rates the extent of drooling over the past week using 10 questions on a scale of 1 (not at all) to 10 (a lot). The slurp test was also administered, which involves measuring the time to drink $4 \mathrm{oz}$ of water through a straw. ${ }^{30}$

A severity scoring system was developed by the study team to incorporate ambulatory, respiratory, and feeding status. Scores were calculated for each participant using the following formula $(6 \times$ ambulatory $[$ no $=1$, yes $=0])+(2 \times$ respiratory support [invasive $=3$, noninvasive day and night $=2$, noninvasive night only $=1$, no support $=0])+($ feeding tube [yes $=1$, no $=0])=$ severity score. Scores were categorized as mild $(0-2)$ or not mild (3-13). Ambulatory status was assessed only in participants $>2$ years of age. Clinical classifications were based on the criteria from Ryan et al. ${ }^{18}$ Two participants from the 2016 cohort were excluded from clinical classification due to incomplete data.

\section{Data Analysis}

Missing data were excluded from analyses. Analysis consisted mainly of descriptive statistics, while a subset of data were analyzed with $t$ tests to determine statistical significance based on 2 -sided $p$ values being $<0.05$. Data analysis was completed at the Hospital for Sick Children.

\section{Data Availability}

Deidentified data will be shared on request with any qualified investigator. Supplemental figures (figures e-1-e-6) are available from Dryad: doi.org/10.5061/dryad.z08kprrb9.

\section{Results}

\section{General Cohort Characteristics}

Fifty-seven individuals with confirmed NM were enrolled in either 2009 or 2016, with 16 individuals assessed at both time points. At study enrollment, 1 deceased individual was included. General characteristics of the cohort are presented in figure 1A. The diagnosis of NM was established by muscle biopsy in 49 of 50 cases. All individuals who pursued genetic testing had, at minimum, a multigene panel consisting of known NM genes. Thirty-five percent $(\mathrm{n}=20)$ of the cohort had causative mutations in NEB, 32\% $(\mathrm{n}=18)$ in ACTA1, and $4 \%(\mathrm{n}=2)$ in
TPM2; 30\% ( $\mathrm{n}=17)$ were genetically unresolved despite extensive testing (figure 1B). Fifty-four percent $(n=30)$ of the cohort conformed to the typical congenital categorization, with $20 \%(\mathrm{n}=11)$ severe congenital and 22\% ( $\mathrm{n}=12)$ intermediate congenital (figure 1C). Genotypes were distributed equally among the different categories (figure e-1A, doi.org/10.5061/ dryad.z08kprrb9).

\section{Overall Disease Severity}

We first looked at the extent of interventional support required as a means of evaluating overall disease severity. To do this, we focused on ventilator, wheelchair, and feeding tube dependence. Fifty-eight percent of individuals (31 of 53) required at least 1 type of support, and 26\% (8 of 31) required support across all 3 domains (figure e-1B, doi.org/10.5061/dryad. z08kprrb9). In terms of maximum respiratory function, $60 \%$ of individuals needed ventilatory assistance, divided approximately equally between invasive (32\%) and noninvasive (28\%) support (figure 1D). Median age at invasive ventilatory support initiation was 0.9 years, and median age at noninvasive ventilatory support initiation was 4 years. Fifty-one percent of individuals used feeding tubes. Of the participants $>2$ years of age, $30 \%$ required wheelchair assistance. An overall severity score was calculated for each individual that included weighted values for ambulatory status, respiratory support, and feeding support. The cohort was split almost evenly between mild (no support required, feeding tube only, or nocturnal noninvasive respiratory support $)(\mathrm{n}=25)$ and nonmild $(\mathrm{n}=28)$ scores.

\section{Motor Function Evaluation}

We next analyzed muscle strength and function using a combination of standard physical examination and quantitative measures. Direct muscle testing using MRC grading revealed that strength was typically only mild to moderately impaired, and essentially all muscle groups assessed had a median value of at least antigravity strength (figure $2 \mathrm{~A}$ ). For the overall cohort, the most affected muscles were neck flexors and hip girdle. To objectively quantify muscle strength, we performed myometry at the elbow, knee, and hip joints. All individuals except 2 had reduced values, typically $<50 \%$ of normalized values (figure e- 2 , doi.org/10.5061/dryad.z08kprrb9). Elbow flexion and extension were similarly affected, while knee extension was more severely impaired. We also examined joint range of motion using goniometric measurements of the elbow, knee, and ankle. Most individuals had normal or mildly reduced (30 of 38) range of motion, only 5 individuals had severe (grade 4) restriction at any 1 joint (figure $2 \mathrm{~B}$ ). The goniometry scores corroborated the overall physical assessment, in which examiners noted very few joint contractures. When surveyed, additional infrequent muscle complaints reported included myalgias ( 7 of $33,21 \%)$ and muscle slowness ( 2 of $31,6.5 \%$ ).

\section{Quantitative Motor Measurements}

We complemented direct physical examination with a battery of quantitative muscle-related measures, including the Gowers maneuver, 4-stair climb, and 10-m run test (figure 3, A and B). Fifty percent of individuals in the study were unable to rise from 
Figure 1 General Cohort Characteristics

\begin{tabular}{|c|c|c|}
\hline \multicolumn{3}{|l|}{ Cohort details } \\
\hline & \multicolumn{2}{|c|}{$\mathrm{N}$} \\
\hline 2009 total & \multicolumn{2}{|c|}{$32(2009$ exclusive $n=16)$} \\
\hline 2016 total & \multicolumn{2}{|c|}{$41(2016$ exclusive $n=25)$} \\
\hline Overlap & \multicolumn{2}{|l|}{16} \\
\hline Overall & \multicolumn{2}{|l|}{57} \\
\hline \multirow[t]{2}{*}{ Male:Female } & \multicolumn{2}{|c|}{27 (47\%):30 (53\%) } \\
\hline & \multicolumn{2}{|c|}{ Years (median; mean) } \\
\hline Range & \multicolumn{2}{|c|}{$1-57(8.60 ; 14.3)$} \\
\hline Age at diagnosis & \multicolumn{2}{|c|}{$(0.96 ; 4.26)$} \\
\hline Age at onset & \multicolumn{2}{|c|}{$(0.00 ; 0.26)$} \\
\hline \multirow{4}{*}{$\begin{array}{c}\text { Age at study } \\
\text { entry }^{a}\end{array}$} & Years & $\mathrm{N}$ \\
\hline & $\leq 2$ & $7(13 \%)$ \\
\hline & 3 to 17 & $32(57 \%)$ \\
\hline & $\geq 18$ & $17(30 \%)$ \\
\hline
\end{tabular}
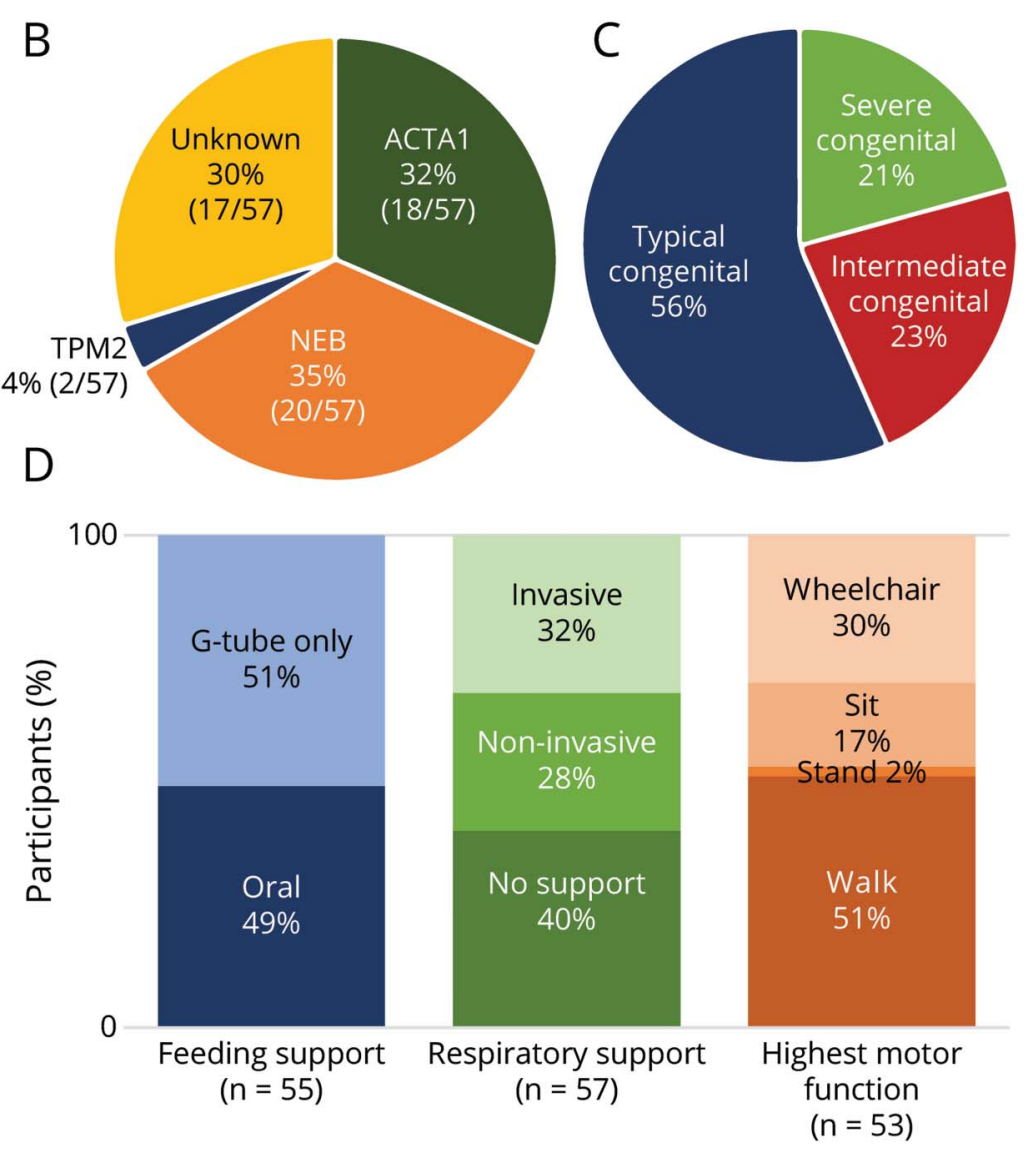

(A) Study cohort characteristics. There were 2 entry points into the study (2009 and 2016 family conferences). Sixteen individuals were assessed at both time points. (B) Genotype breakdown of the study cohort $(n=57)$. (C) Clinical classification of the study cohort. Two participants classified as "other: cardiomyopathy" were are not included. (D) Severity of disease as assessed by feeding, respiratory support, and motor function. Feeding was divided into oral feeding vs exclusively gastrostomy tube (G-tube) fed. Walking was defined as able to walk $10 \mathrm{ft}$. Standing and sitting were defined as able to stand/sit unassisted for 10 seconds. Four participants were excluded from calculations of highest motor function because they were $\leq 2$ years old at the time of survey. Invasive support includes tracheostomy; noninvasive support includes mechanical ventilation mask, bilevel positive airway pressure machine, and continuous positive airway pressure machine.

a age at study entry unknown for one participant.

the floor; $16 \%$ could rise with assistance; $16 \%$ had a classic Gowers sign; $14 \%$ had a modified Gowers sign; and only $7 \%$ rose without difficulty ( $\mathrm{n}=44$ total) (figure 3B). Timed testing of the Gowers sign reflected these changes, with a mean time for those tested of 11.14 seconds (normal 1.35 seconds, $n=15$ ) (figure 3A). ${ }^{24}$ The 4-stair climb was difficult for many participants, with both up (mean 4.51 seconds) and down (mean 3.13 seconds) climbs roughly equally affected $(n=15)$ (figure $3 A$ ). The $10-\mathrm{m}$ run testing, completed by 18 individuals, yielded an average time of 26 seconds, compared to 5.5 seconds for healthy individuals (figure 3A). ${ }^{24}$

We also measured a composite motor score, the MFM, which has been validated in several populations of patients with neuromuscular disease. ${ }^{23}$ The MFM20 mean total score was 35.8 , and there was tremendous variability across the cohort. Only 2 individuals achieved the full score of 60 of 60 (ceiling), while only 1 had a score of 0 of 60 (floor) (figure 3C). Domain 1 scores (standing and transfers) were, on average, the most reduced (mean 8.47 of 24) compared to scores in domains 2 (mean 17.9 of 24) and 3 (mean 9.49 of 12) (figure 3C and figure e-3, doi.org/10.5061/dryad.z08kprrb9).

\section{Non-Muscle-Related Comorbid Conditions}

We examined non-muscle-related symptoms via in-person survey (table 1). Most findings were consistent with those previously reported by Ryan et al. ${ }^{18}$ Scoliosis was the most common additional phenotype, identified in $69 \%$ of individuals. Gastrointestinal ailments were the next most common comorbidity (55\% with dysphagia and $51 \%$ with acid reflux disease). Of note, there was a high prevalence of bone fractures, occurring in $36 \%$ of cases. Cardiomyopathy (13\%), clinical jaundice (13\%), and kidney stones (13\%) were rarely reported. Ten percent of cohort participants had seizures, and learning disability was reported in $17 \%$, suggesting possible CNS involvement in a subset of individuals, similar to results reported by Ryan et al. ${ }^{18}$ All comorbid conditions were patient reported, and confirmation from medical records was not obtained. The 2 most common surgeries performed were spinal fusion/rods $(n=19)$ and contracture releases $(n=10)$. 
A

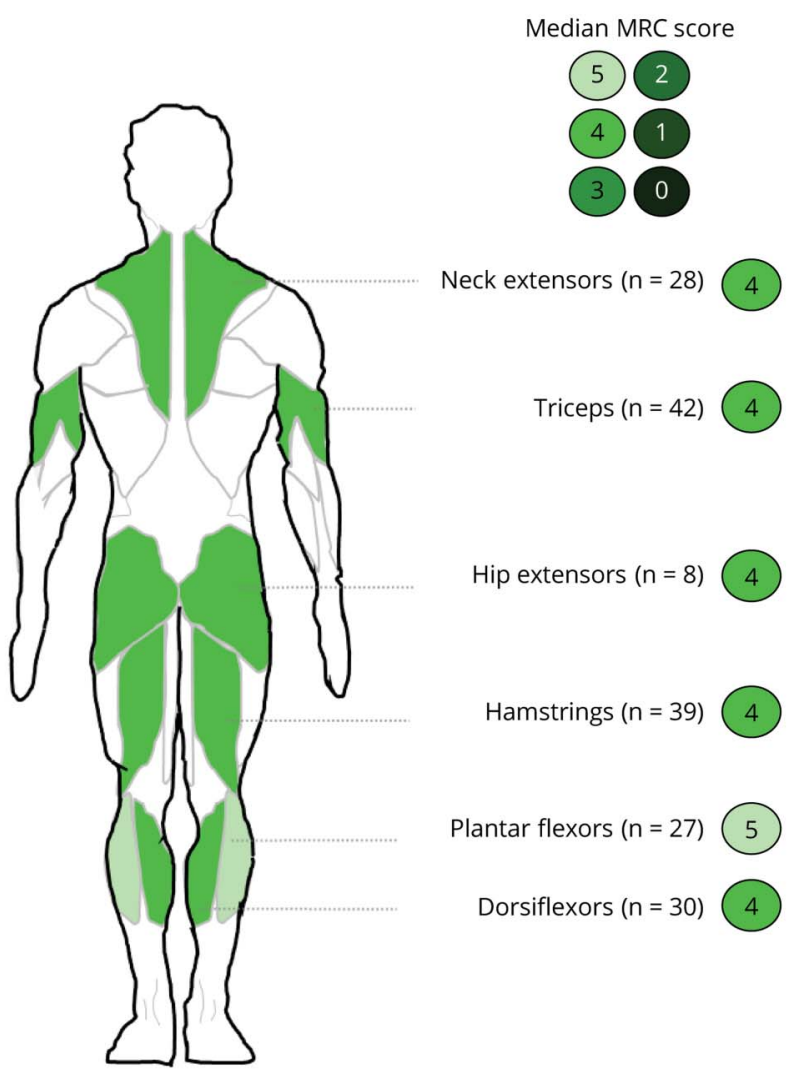

B
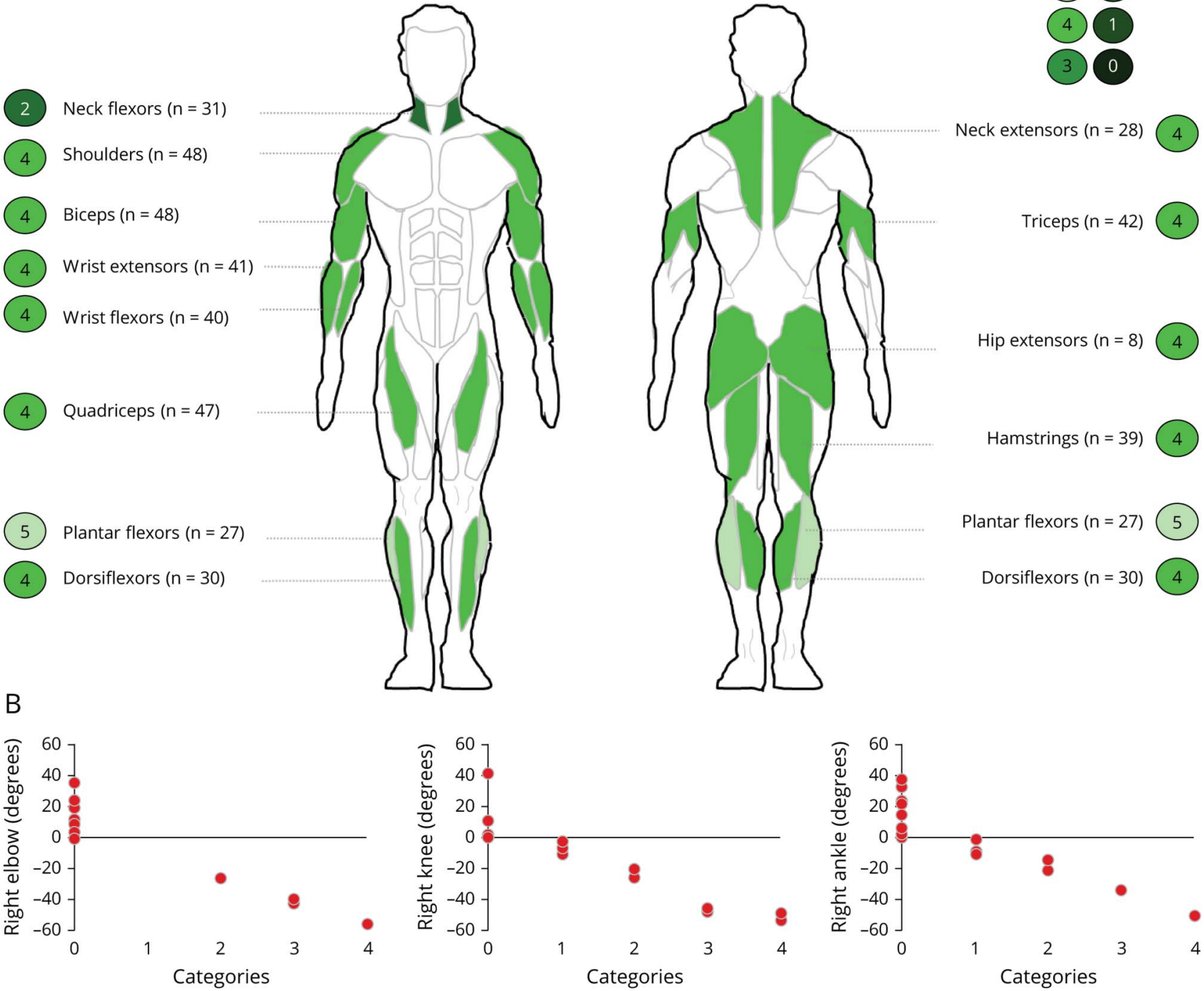

(A) Median Medical Research Council (MRC) scores for nemaline myopathy study cohort. This information was collected on 51 participants from both the 2009 and 2016 cohorts. The most recent MRC score was used for the individuals who participated at both time points. Hip flexion values were excluded from the figure because they could not be displayed in the diagram. Median MRC score for this muscle was 3 with a total of 31 participants assessed. (B) Goniometric scores were categorized for the elbows, knees, and ankles $(n=38)$. Grade $0=$ no contracture/hyperflexibility with increasing joint restriction; grade $4=$ most severe contracture. There was no difference between right and left sides; therefore, only the right side is presented in the figure.

\section{Pulmonary Function Measurements}

Given the high prevalence of respiratory compromise, we examined quantitative measures of respiratory function. Twentyseven participants were able to complete PFTs (figure 4A). Of the measures performed, maximal inspiratory pressure, peak cough flow, and FVC values were lower than the predicted values for the majority of participants $(96 \%[n=26], 81 \%[n=22]$, $65 \%[\mathrm{n}=11]$, respectively) (figure $4 \mathrm{~A}$ and figure e-4A, doi.org/ 10.5061 /dryad.z08kprrb9). This is not surprising because $60 \%$ of the cohort required respiratory support (32\% invasive and $28 \%$ noninvasive support) (figure $1 \mathrm{D}$ ). Thirty participants were not able to complete PFTs: 3 of 30 were too young; 10 of 30 were on invasive ventilatory support; and 7 of 30 lacked coordination/cooperation. No data were available for the remaining 10 participants.

\section{Bulbar Function}

As indicated by the high prevalence of dysphasia (table 1), bulbar function is often impaired in patients with NM. To assess this more thoroughly, we assessed drooling via 2 scales: the Drooling Rating Scale and the Drooling Impact Scale (figure 4, B and C). ${ }^{28,29}$ With the Drooling Rating Scale, approximately one-third of the cohort reported frequent drooling, while a little more than one-third reported no drooling (figure 4B). Drooling severity was moderate to severe in $\approx 50 \%$ of participants (figure $4 \mathrm{C}$ ). With the Drooling Impact Scale, all participants reported median 


\begin{tabular}{|c|c|c|c|c|}
\hline \multicolumn{5}{|c|}{ Quantitative motor measurements } \\
\hline Test & $\mathrm{N}$ & Mean & Median & $\begin{array}{c}\text { Reference values } \\
\text { Mean; Median }\end{array}$ \\
\hline Timed Gowers' (s) & 15 & 11.14 & 8.97 & $1.35 ; 1.28$ \\
\hline 4 stairs up (s) & 15 & 4.51 & 3.8 & NR \\
\hline 4 stairs down (s) & 15 & 3.13 & 2.6 & NR \\
\hline 4 stairs total (s) & 15 & 7.64 & 6.4 & NR \\
\hline $10 \mathrm{MRT}(\mathrm{s})$ & 18 & 26 & 7.4 & $5.5 ; 4.89$ \\
\hline
\end{tabular}

B
Unable to stand from supine position, even with use of a chair
Assisted Gowers'
Full Gowers'
Half Gowers'

Rolls to side and/or stands up with one or both hands on the floor while starting to rise

Stands up without rolling over or using hands
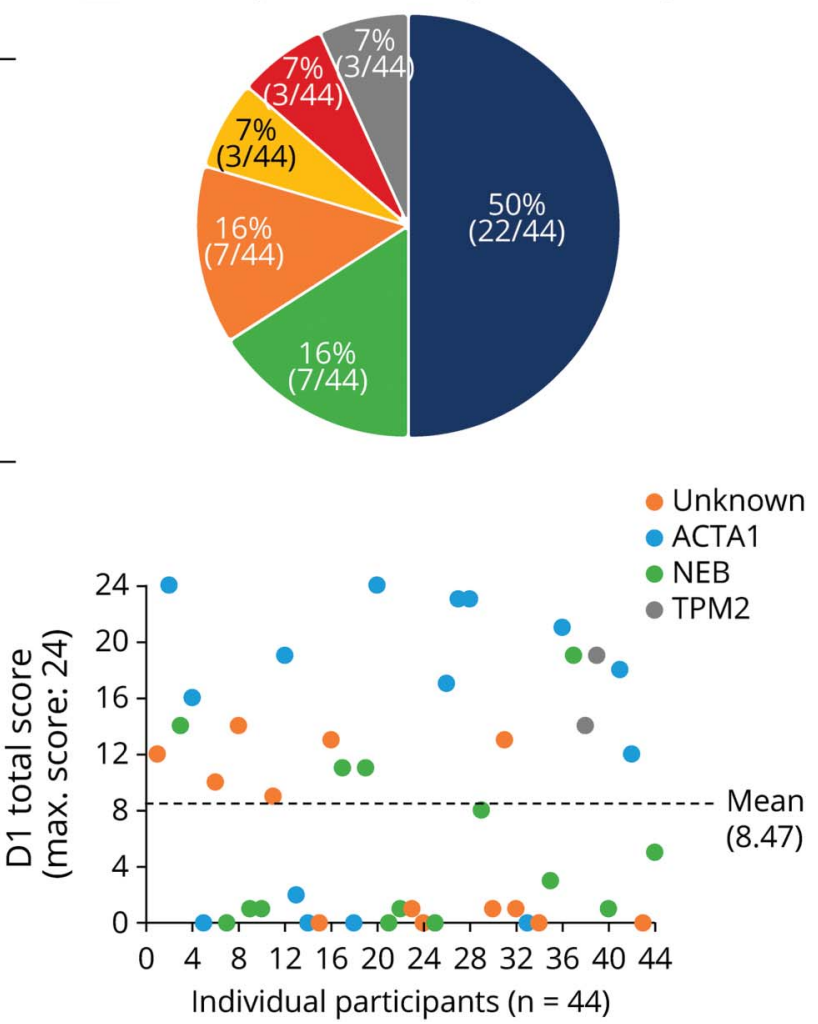

(A) Timed motor assessments in the study cohort. Reference values for healthy individuals were adapted from Pereira et al. ${ }^{24}$ (B) Gowers maneuver was assessed in 44 participants. Assisted Gowers: requires furniture for assistance in rising from supine to full upright posture; full Gowers: rolls over, stands up with both hands "climbing up" the legs to above the knees to achieve full upright posture; and half Gowers: rolls over, stands up with 1 hand support on lower legs. (C) Motor Functions Measure 20 (MFM20) scores (total and domain 1 [standing and transfers] of MFM20 [D1]) color coded by genotype. Max = maximum; $\mathrm{NR}=$ no reference values found; $10 \mathrm{MRT}=10-\mathrm{m}$ run time .

values of 1 to 2 of 10 for all questions, indicating low extent and impact of drooling. We also examined an exploratory outcome measure of bulbar function called the slurp test. ${ }^{30}$ All 23 individuals who attempted the test had abnormal values (below the mean for age), with most times being 2 to 3 times longer than those for age-related healthy individuals (figure 4D, e-4B, doi. org/10.5061/dryad.z08kprrb9). Exceptions were 2 individuals who had slurp test values within the normal reference range but below the normal mean value for age.

\section{Longitudinal Assessment}

Sixteen individuals were evaluated longitudinally, with examinations in 2009 and 2016. In this group, we focused primarily on the general extent of disability and quantifiable outcomes. In 2009, the median age of this subset of our cohort was 4 years (mean 6.6 years, range $1.5-20$ years), and in 2016, the median age was 12.9 years (mean 15.2 years, range 9-28.7 years). In general, the disease was quite stable. Three individuals lost ambulation $(n=8$ ambulators in 2009); 3 continued using a wheelchair; and 6 maintained independent ambulation. In terms of feeding support, $43 \%$ continued to require a feeding tube $(n=6), 43 \%$ fed independently at both time points $(n=6)$, while 2 became free of gastrostomy tube support. For respiratory support, 3 developed the need for respiratory support (noninvasive $\mathrm{n}=1$, invasive $\mathrm{n}=$ 2 ), while no participants who previously required support improved in status (table 2 and figure e-5A, doi.org/10.5061/dryad. z08kprrb9). For those experiencing decline, loss of ambulation occurred at 5, 10, and 11 years of age. Initiation of invasive respiratory support occurred at 3 years (age unknown for one patient) and noninvasive support at 6 years of age. 
Table 1 Nonmuscular Comorbidities in Nemaline Myopathy Study Cohort

\begin{tabular}{|c|c|c|c|}
\hline $\begin{array}{l}\text { Comorbidity } \\
\text { by System }\end{array}$ & $\begin{array}{l}\text { Patients } \\
\text { Experiencing, } \mathrm{n}\end{array}$ & $\begin{array}{l}\text { Patients } \\
\text { Surveyed, n }\end{array}$ & Percentage \\
\hline \multicolumn{4}{|l|}{ Eye } \\
\hline Myopia & 9 & 36 & 25 \\
\hline Hyperopia & 6 & 38 & 16 \\
\hline Strabismus & 5 & 39 & 13 \\
\hline \multicolumn{4}{|l|}{ Ear } \\
\hline Hearing loss & 6 & 39 & 15 \\
\hline \multicolumn{4}{|l|}{ Cardiac } \\
\hline Arrhythmia & 4 & 39 & 10 \\
\hline Heart murmur & 3 & 40 & 7.5 \\
\hline Cardiomyopathy & 5 & 40 & 13 \\
\hline $\begin{array}{l}\text { Patent foramen } \\
\text { ovale }\end{array}$ & 5 & 40 & 13 \\
\hline Atrial septal defect & 1 & 39 & 2.6 \\
\hline \multicolumn{4}{|l|}{ Gastrointestinal } \\
\hline Dysphagia & 22 & 40 & 55 \\
\hline Gastroparesis & 4 & 36 & 11 \\
\hline Achalasia & 2 & 37 & 5.4 \\
\hline Chronic constipation & 20 & 48 & 42 \\
\hline Gallstones & 1 & 38 & 2.6 \\
\hline Kidney stones & 5 & 40 & 13 \\
\hline \multicolumn{4}{|l|}{ Liver } \\
\hline Jaundice & 5 & 38 & 13 \\
\hline $\begin{array}{l}\text { Abnormal liver } \\
\text { function test }\end{array}$ & 1 & 37 & 2.7 \\
\hline \multicolumn{4}{|l|}{ Genitourinary } \\
\hline $\begin{array}{l}\text { Chronic urinary } \\
\text { infections }\end{array}$ & 3 & 38 & 7.9 \\
\hline Cryptorchidism & 5 & 31 & 16 \\
\hline \multicolumn{4}{|l|}{ Thyroid } \\
\hline Hyperthyroidism & 1 & 39 & 2.6 \\
\hline \multicolumn{4}{|l|}{ Skeletal } \\
\hline Torticollis & 7 & 40 & 18 \\
\hline Pectus excavatum & 15 & 44 & 34 \\
\hline Pectus carinatum & 8 & 40 & 20 \\
\hline Scapular winging & 12 & 35 & 34 \\
\hline Hip dysplasia & 8 & 37 & 22 \\
\hline Pes planus & 12 & 38 & 32 \\
\hline Pes cavus & 3 & 39 & 7.7 \\
\hline Scoliosis & 27 & 39 & 69 \\
\hline \multicolumn{4}{|l|}{ Neurologic } \\
\hline Seizures & 4 & 40 & 10 \\
\hline
\end{tabular}

One exception to disease stability was scoliosis, which developed and/or worsened in $85 \%$, with rapid worsening in 48\% (figure e-5B, doi.org/10.5061/dryad.z08kprrb9). Average age of rapid worsening was 9 years, requiring surgery in $38 \%$ of patients by 11 years of age on average.

For quantifiable motor outcomes, we measured joint angles and MFM20. Six of 14 participants lost measurable range of motion by goniometry (table 2 and figure e-5C, doi.org/10. 5061/dryad.z08kprrb9), and 7 of 13 (54\%) showed a >5point decline in MFM20 (table 2 and figure e-5D). Conversely, only 1 of 13 (8\%) improved by $>5$ points on MFM20. These scales suggest some element of disease progression. Quantification of respiratory function was not analyzed because only 4 participants completed PFTs at both time points.

\section{Genotype-Phenotype Correlations}

For assessment of potential genotype-phenotype correlations (figure 5 and figure e-6, doi.org/10.5061/dryad.z08kprrb9), we binned subgroups into ACTA1-related NM $(\mathrm{n}=17)$, NEB-related NM $(\mathrm{n}=17)$, or unknown genotype $(\mathrm{n}=17)$. Two cases with TPM2 mutations and 4 cases with incomplete data were excluded from this analysis. The primary points of comparison were the extent of disabilities as determined by feeding, breathing, and ambulatory support (figure 5, A-C and figure e-6). There was no statistical difference in the number of supports required between ACTA1 and NEB patients. Conversely, unknown cases were more likely to need 2 or 3 supports (53\%). There was, however, a difference between ACTA1 and NEB in terms of feeding support in that more individuals with ACTA1 mutations required gastrostomy tubes (67\% vs 32\%) (figure 5, B and C). Differences in lung function via PFTs could not be assessed because the sample size was too small. Direct strength testing was compared between NEB and ACTA1. Median MRC scores were roughly the same between groups, including distal musculature. We also looked at a quantitative measure, MFM20. There was no difference between the means of ACTA1 and NEB in composite MFM20 scores, while the unknown genotype group had a significantly lower mean score $(p=0.03)$.

\section{Discussion}

We present a comprehensive cross-sectional study of 57 individuals with NM and report pilot longitudinal data on a subset of participants $(n=16)$. These data provide important insights into outcome measures with potential utility for future clinical trials. Mortality was not assessed in this study because only 1 deceased individual was included. Overall, NM is a severe, debilitating disorder associated with disability across multiple domains. There is a high degree of comorbid conditions, with more than half of individuals requiring some form of interventional support. Breathing and feeding are most commonly affected, reflecting bulbar and axial weakness, which appears more severe compared to extremity weakness and dysfunction. The prominence of axial weakness is further 
Figure 4 Pulmonary Function Measurements and Bulbar Function

\section{A}

\begin{tabular}{ccc}
\hline $\begin{array}{c}\text { PFT } \\
\text { assessment }\end{array}$ & $\begin{array}{c}\text { Actual } \\
\text { (range: mean;median) }\end{array}$ & $\begin{array}{c}\text { Participants } \\
\text { below normal } \\
\text { reference range }\end{array}$ \\
\hline FVC & $2.4 ; 2.1$ & $11 / 17(65 \%)$ \\
$\begin{array}{c}\text { MIP } \\
\left(\mathrm{Cm} \mathrm{H} \mathrm{H}_{2} \mathrm{O}\right)\end{array}$ & $26.4 ; 23$ & $26 / 27(96 \%)$ \\
$\begin{array}{c}\mathrm{MEP} \\
\left(\mathrm{Cm} \mathrm{H} \mathrm{H}_{2} \mathrm{O}\right)\end{array}$ & $35.5 ; 34$ & $\mathrm{~N} / \mathrm{A}$ \\
$\begin{array}{c}\mathrm{PCF} \\
(\mathrm{L} / \mathrm{min})\end{array}$ & $168 ; 162$ & $22 / 27(81 \%)$ \\
\hline
\end{tabular}

C. Drooling severity $(n=38)$

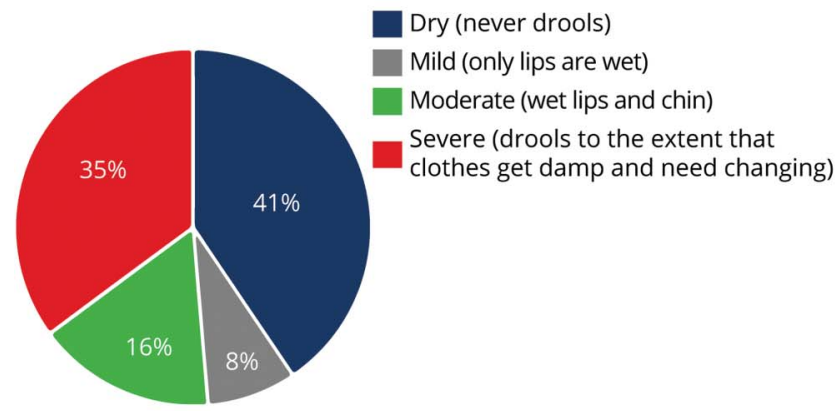

B. Drooling frequency $(n=38)$

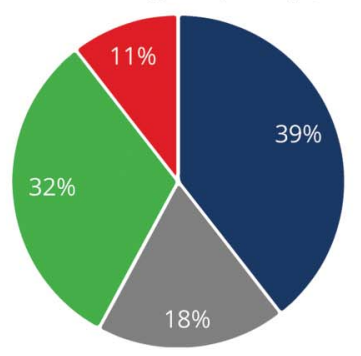

No drooling (dry)

Occasional drooling (not every day)

Frequent drooling

(every day but not all the time)

Constant drooling (always wet)

\section{D}

\begin{tabular}{ccc}
\hline \multicolumn{3}{l}{ Slurp test values and reference ranges } \\
\hline $\begin{array}{c}\text { Age } \\
\text { (years) }\end{array}$ & $\begin{array}{c}\text { Nemaline study } \\
\text { participants, seconds } \\
\text { Mean (range; median; } N)\end{array}$ & $\begin{array}{c}\text { Normal reference } \\
\text { values, seconds } \\
\text { Mean (range) }\end{array}$ \\
\hline 5 to 6 & $212(n=1)$ & $20(11-55)$ \\
7 to 8 & $58(n=1)$ & $12(8-20)$ \\
9 to 10 & $19.4(14.8-24 ; 19.4 ; 2)$ & $8(6-27)$ \\
11 to 12 & $22(13-39 ; 13.5 ; 3)$ & $5(4-12)$ \\
$>13(15-57)$ & $22(5-68 ; 16.6 ; 15)$ & NR \\
\hline
\end{tabular}

(A) Summary of pulmonary function test (PFT) assessments in nemaline myopathy study cohort compared to reference values ( $n=27)$ (Quanjer et al., ${ }^{25}$ Verma et al. ${ }^{26}$ Bianchi and Baiardi ${ }^{27}$ ). (B) Drooling Rating Scale: frequency. (C) Drooling Rating Scale: severity. (D) Slurp test was assessed in 23 participants with reference values (Hudspeth et al. ${ }^{30}$ ). FVC = forced vital capacity; MEP = maximum inspiratory and expiratory pressures; MIP = maximal inspiratory pressure; $\mathrm{NR}=$ no reference values available; $\mathrm{PCF}=$ peak cough flow.

seen through the high proportion of participants with scoliosis and by the fact that scoliosis was the disease feature most likely to change over time. Outside of scoliosis, evidence pointed to little disease progression over time, particularly in terms of requirements for assistive support devices.

One of the most impactful aspects of our study is that it examined and defined potential outcome measures in patients with NM. Previous natural history and genotype-phenotype studies were limited to retrospective chart reviews and therefore did not assess outcome measures. We addressed this need by evaluating several motor measures, pulmonary function studies, and an exploratory measure of bulbar function. As with other neuromuscular disorders, MFM scores were reduced in most patients with NM, with most exhibiting the largest reduction in domain 1 . There were very few floor and ceiling effects in our cohort. In our longitudinal cohort, MFM changed in most individuals, indicating that it may show suitable change to be used as a primary outcome in an interventional study. However, our study size was limited, and our data

Table 2 Prospective Longitudinal Assessment

\begin{tabular}{lllll}
\hline Type of Support $(\mathbf{n})$ & Improved, $\mathbf{n}$ & Declined, $\mathbf{n}$ & Stable Without Support, $\mathbf{n}$ & Stable With Support, $\mathbf{n}$ \\
\hline Feeding support (14) & 2 & 0 & 6 (Oral) & 6 (G-tube) \\
\hline Ambulatory support (12) & 0 & 3 & 6 (Walking) & 3 (Wheelchair) \\
\hline Respiratory support (16) & 0 & $3(\mathrm{NI} \rightarrow$ I [2], NS $\rightarrow$ NI [1]) & 7 (Independent) & 6 (NI [3], I [3]) \\
\hline Scoliosis (16) & 0 & 7 & 3 (No scoliosis) & 6 (Stable with scoliosis) \\
\hline Goniometry (14) & 2 & 6 & 4 (Stable with no contractures) & 2 (Stable with contractures) \\
\hline MFM20 total score (13) & 1 (>5-Point change) & 7 (>5-Point change) & 5 ( (s5-Point change) &
\end{tabular}

Abbreviations: G-tube = gastrostomy tube; I = invasive support (tracheostomy); MFM20 = Motor Function Measure 20; NI = noninvasive support (mechanical ventilation mask, bilevel positive airway pressure machine, continuous positive airway pressure machine). 


\section{A}

ACTA1

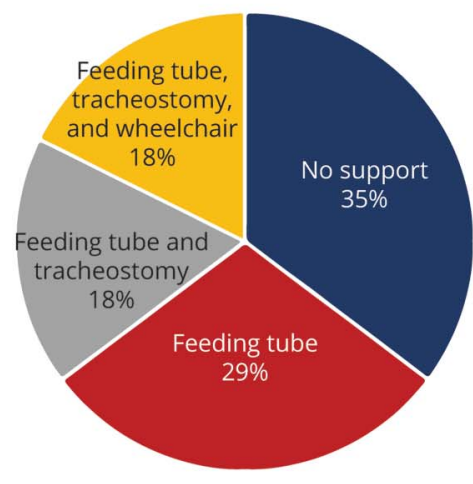

B

ACTA1

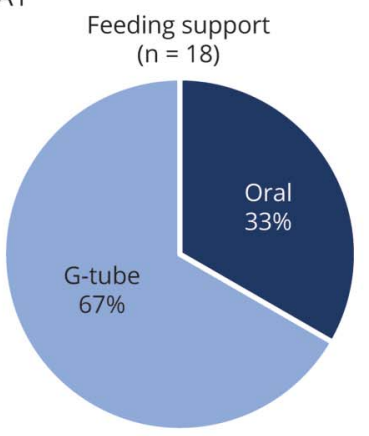

C

NEB

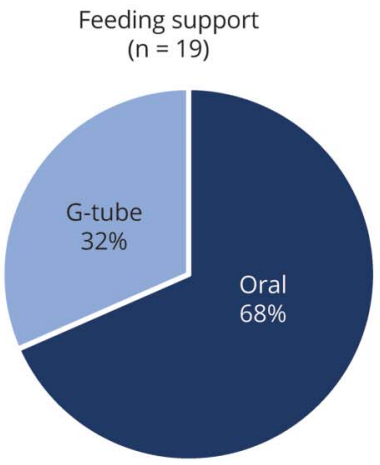

NEB

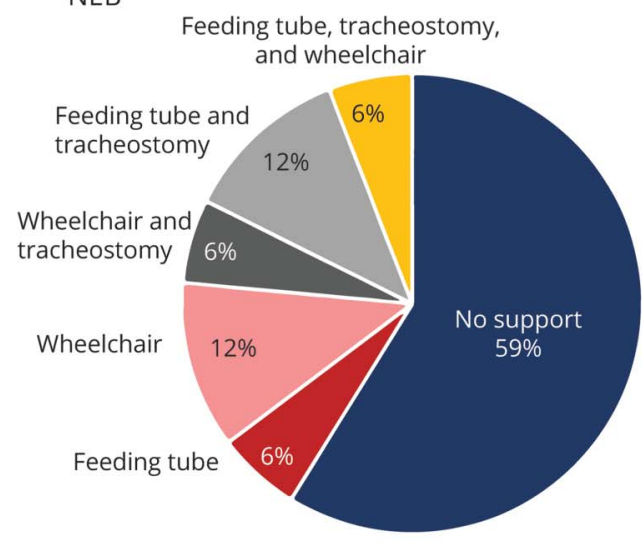

Feeding tube and tracheostomy

Unknown

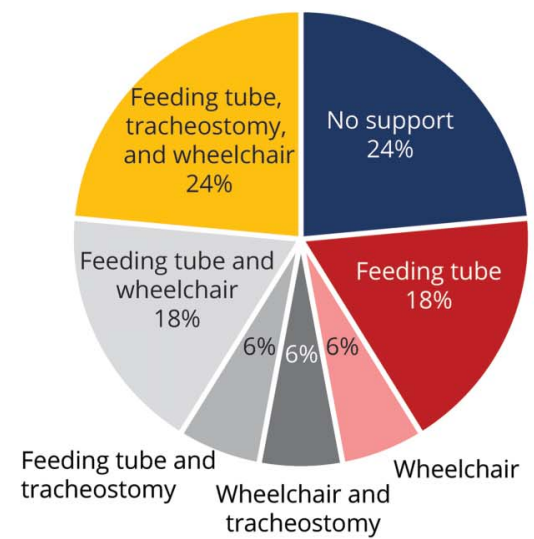

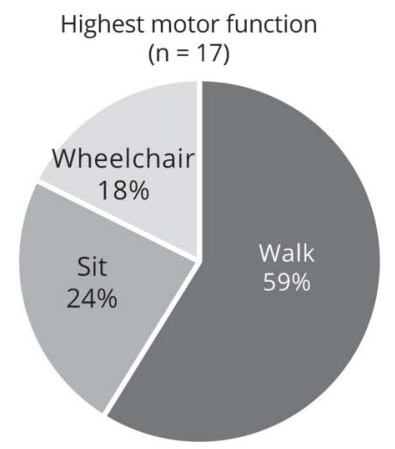
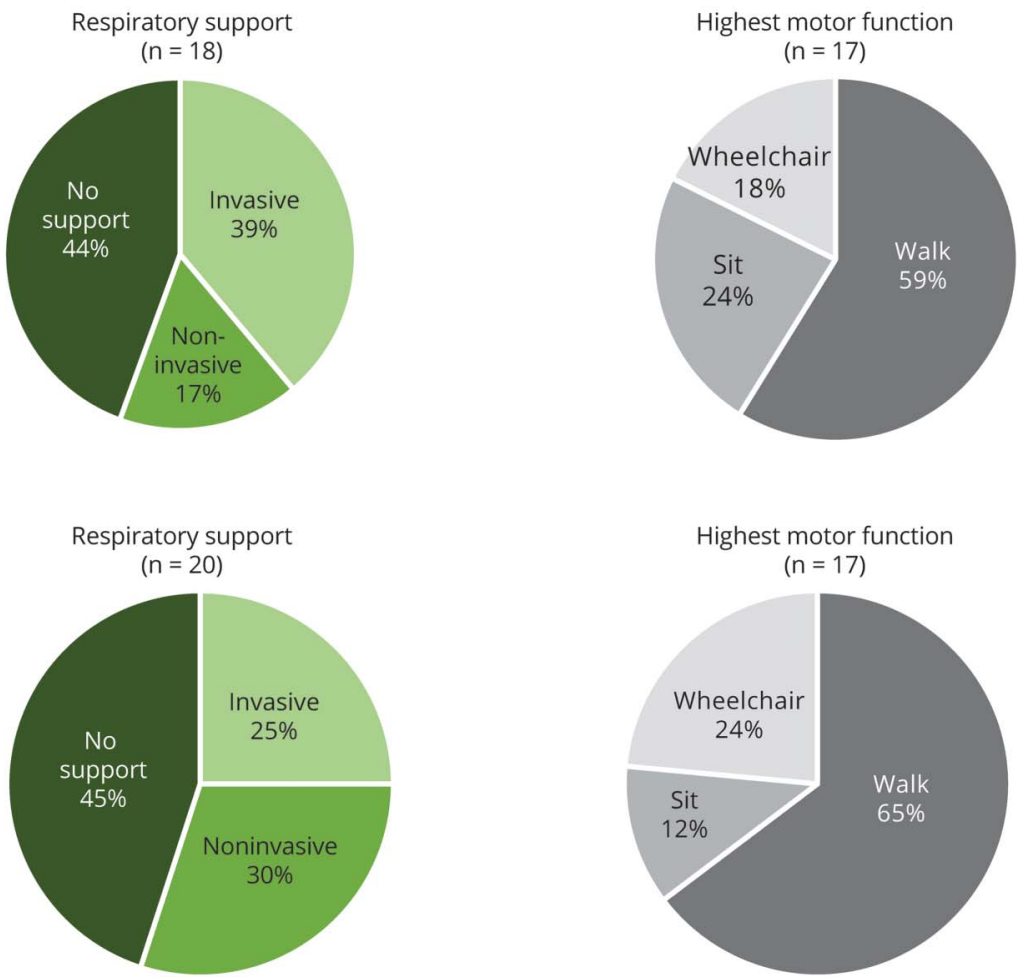

(A) For participants who harbored a pathogenic variant in ACTA1 or NEB, specific technology supports are broken down by wheelchair dependence, feeding tube, and tracheostomy. (B and C) Breakdown of the extent of feeding support, respiratory support, and highest motor function at the time of most recent survey completion by genotype. Participants $\leq 2$ years old were excluded from highest motor function calculations. Walking was defined as able to walk $10 \mathrm{ft}$. Sitting was defined as able to sit for 10 seconds. Invasive support includes tracheostomy; noninvasive support includes mechanical ventilation mask, bilevel positive airway pressure machine, and continuous positive airway pressure machine. G-tube = gastrostomy tube.

points were separated by several years. In the future, a more thorough examination of MFM20 and MFM32 (as well as the other measures) is warranted with an increased number of patients and more frequent assessments to determine whether and how best to use this scale for this population. In addition, it will be critical to correlate changes in MFM scores with clinically meaningful disease processes so that a minimal clinical change in the score can be specifically established for NM.
One feature of our study was the examination of the slurp test in our cohort. This test was previously examined in a mixed cohort of neuromuscular diseases and healthy controls. ${ }^{30}$ All individuals with NM evaluated with this test had abnormal values, with times that were often more than 2- to 3-fold slower than normal. Thus, this measure holds promise as an easy and clinically relevant outcome in NM. As with MFM, future studies will be required to assess its true variability and rate of change. 
Previous studies of NM examined cohorts with little or no information available about genetic etiology. For example, the study by Ryan et al. ${ }^{18}$ was done when there was limited access to $N E B$ sequencing, and therefore, a large number of patients in their cohort were genetically unsolved. Yin et al. ${ }^{19}$ did not perform any genetic testing in their cohort. Here, we have been better able to assess genotype-phenotype correlations across our cohort because 40 of 57 participants had a genetic diagnosis. Unsurprisingly, patients with mutations of the NEB or ACTA1 genes represented the majority of cases, consistent with previous data showing that these are by far the most common genotypes. Thus, our primary comparison was between these 2 subgroups. Keeping in mind the caveat that the most severely affected patients may have been underrepresented, it was striking that the phenotypic characteristics of patients with both genotypes were quite similar, with an equivalent extent of disabilities similar to the findings of Colombo et al. ${ }^{21}$ We did find, however, that individuals with ACTA1 mutations had more feeding difficulties, as also reported by Maggi et al. ${ }^{20}$

Despite comprehensive genetic testing, we had a relatively large group of genetically unsolved cases. Ongoing investigations using modalities such as whole-genome sequencing combined with RNA sequencing ${ }^{32-34}$ will, we hope, elucidate the cause of disease in many of these individuals. Of note, our unsolved cohort appeared overall to be more severely affected compared to the $A C T A 1$ and $N E B$ subgroups. It remains to be confirmed if they will fit genetically with our classic definition of $\mathrm{NM}$ as a disease due to mutations in genes encoding thin filament-associated proteins.

Except for scoliosis and decline in MFM20 scores, our longitudinal assessment showed that the disease process is largely stable over time, similar to what Ryan et al found. ${ }^{18}$ Few individuals who did not already require breathing or walking support developed this need over a 7-year period. While no dramatic functional changes were noted, as described above, more than half of the cohort had a $>5$-point decline in MFM20, indicating possible progression in motor phenotype. The previously established minimal clinically important difference for MFM32 in other neuromuscular disorders is 5 points $(5.2 \%) .{ }^{31}$ While an minimal clinically important difference has not be established for MFM20, a 5-point change would represent an $8.3 \%$ difference and would suggest that this change is likely clinically meaningful. Future studies will be needed to determine whether the decline in MFM score is due to progressive muscle weakness or instead reflects increased motor difficulties associated with age and weight/size but not overtly reduced muscle strength.

There are caveats to our longitudinal analysis, the most prominent being that we assessed only 16 individuals at both time points. An additional limitation is a likely bias of ascertainment in favor of participants with milder clinical presentations compatible with traveling to a family conference. There is clearly a population of severely affected patients who do not survive the first few years of life and would not be enrolled in a study such as this. In addition, medically fragile and ventilator-dependent patients are potentially less likely to participate, particularly if air travel is required to attend the conference. Expanding the study to a larger, more representative group of patients is required for a more complete understanding of outcome measures and disease progression across the spectrum of NM presentations.

We present a comprehensive cross-sectional study with a longitudinal component. This study provides new and updated information on the NM disease process, which should guide clinical care. We also investigate potential outcome measures for future clinical trials and establish that the MFM20/32, PFTs, and slurp test may all provide meaningful data for testing interventions to treat NM.

\section{Acknowledgment}

The authors are deeply grateful for the families who participated in the study and A Foundation Building Strength for their funding and for allowing the authors to run the study at the family meetings. Special thanks go to Marc Guillet, who has been a driving force and inspiration behind the organization of this study. The authors also acknowledge and thank Rebekah Hunter for her assistance in manuscript preparation by reviewing manuscript requirements as per the Neurology $y^{\circledR}$ website and adding references.

\section{Study Funding}

This study was funded by A Foundation Building Strength and relied on genotypic data developed with support from the Muscular Dystrophy Association (United States) and grants R01HD075802 and U54HD090255 from the National Institute of Child Health and Human Development of the NIH.

\section{Disclosure}

The authors report no disclosures relevant to the manuscript. Go to Neurology.org/N for full disclosures.

\section{Publication History}

Received by Neurology April 28, 2020. Accepted in final form December 7, 2020.

\section{Appendix Authors}

\begin{tabular}{|c|c|c|}
\hline Name & Location & Contribution \\
\hline $\begin{array}{l}\text { Kimberly } \\
\text { Amburgey, MS }\end{array}$ & $\begin{array}{l}\text { Hospital for Sick } \\
\text { Children, Toronto, } \\
\text { Ontario, Canada }\end{array}$ & $\begin{array}{l}\text { Design and } \\
\text { conceptualized the } \\
\text { study, data collection } \\
\text { and analysis, drafting } \\
\text { and revision of the } \\
\text { manuscript }\end{array}$ \\
\hline $\begin{array}{l}\text { Meryl Acker, } \\
\text { MSc }\end{array}$ & $\begin{array}{l}\text { Hospital for Sick } \\
\text { Children, Toronto, } \\
\text { Ontario, Canada }\end{array}$ & $\begin{array}{l}\text { Data analysis, drafted } \\
\text { figures and tables, } \\
\text { manuscript revision }\end{array}$ \\
\hline
\end{tabular}


Appendix (continued)

\begin{tabular}{|c|c|c|}
\hline Name & Location & Contribution \\
\hline $\begin{array}{l}\text { Samia Saeed, } \\
\text { BSc }\end{array}$ & $\begin{array}{l}\text { Princess Margaret } \\
\text { Hospital, Toronto, } \\
\text { Ontario, Canada }\end{array}$ & $\begin{array}{l}\text { Data analysis, drafted } \\
\text { figures and tables }\end{array}$ \\
\hline $\begin{array}{l}\text { Reshma Amin, } \\
\text { MD }\end{array}$ & $\begin{array}{l}\text { Hospital for Sick } \\
\text { Children, Toronto; } \\
\text { University of Toronto, } \\
\text { Ontario, Canada }\end{array}$ & $\begin{array}{l}\text { Data collection, provided } \\
\text { input on study design, } \\
\text { revision of the } \\
\text { manuscript }\end{array}$ \\
\hline $\begin{array}{l}\text { Alan H. Beggs, } \\
\text { PhD }\end{array}$ & $\begin{array}{l}\text { Boston Children's } \\
\text { Hospital, Boston, } \\
\text { Harvard Medical School, } \\
\text { Boston }\end{array}$ & $\begin{array}{l}\text { Data collection, provided } \\
\text { input on study design, } \\
\text { revision of the } \\
\text { manuscript }\end{array}$ \\
\hline $\begin{array}{l}\text { Carsten G. } \\
\text { Bönnemann, MD }\end{array}$ & $\begin{array}{l}\text { National Institutes of } \\
\text { Health, Bethesda }\end{array}$ & $\begin{array}{l}\text { Data collection, provided } \\
\text { input on study design }\end{array}$ \\
\hline $\begin{array}{l}\text { Michael Brudno, } \\
\text { PhD }\end{array}$ & $\begin{array}{l}\text { University of Toronto, } \\
\text { Toronto, Hospital for } \\
\text { Sick Children, Toronto }\end{array}$ & $\begin{array}{l}\text { Data collection, provided } \\
\text { input on study design, } \\
\text { drafted electronic data } \\
\text { collection forms }\end{array}$ \\
\hline $\begin{array}{l}\text { Andrei } \\
\text { Constantinescu, } \\
\text { MD }\end{array}$ & $\begin{array}{l}\text { Columbia University } \\
\text { Irving Medical Center, } \\
\text { NY }\end{array}$ & Data collection \\
\hline $\begin{array}{l}\text { Jahannaz } \\
\text { Dastgir, MD }\end{array}$ & $\begin{array}{l}\text { Goryeb Children's } \\
\text { Hospital, Morristown }\end{array}$ & Data collection \\
\hline $\begin{array}{l}\text { Mamadou } \\
\text { Diallo, MS, MS }\end{array}$ & $\begin{array}{l}\text { Hospital for Sick } \\
\text { Children, Toronto }\end{array}$ & $\begin{array}{l}\text { Statistical analysis and } \\
\text { interpretation }\end{array}$ \\
\hline $\begin{array}{l}\text { Casie A. Genetti, } \\
\text { MS }\end{array}$ & $\begin{array}{l}\text { Boston Children's } \\
\text { Hospital, Harvard } \\
\text { Medical School, MA }\end{array}$ & $\begin{array}{l}\text { Data collection, revision } \\
\text { of the manuscript }\end{array}$ \\
\hline $\begin{array}{l}\text { Michael Glueck, } \\
\text { PhD }\end{array}$ & $\begin{array}{l}\text { University of Toronto, } \\
\text { Ontario, Canada }\end{array}$ & $\begin{array}{l}\text { Data collection, drafted } \\
\text { electronic data collection } \\
\text { forms }\end{array}$ \\
\hline $\begin{array}{l}\text { Stacy Hewson, } \\
\text { MSc }\end{array}$ & $\begin{array}{l}\text { Hospital for Sick } \\
\text { Children, Toronto, } \\
\text { Ontario, Canada }\end{array}$ & $\begin{array}{l}\text { Data collection, data } \\
\text { analysis }\end{array}$ \\
\hline $\begin{array}{l}\text { Courtney Hum, } \\
\text { MSc }\end{array}$ & $\begin{array}{l}\text { Mount Sinai Hospital, } \\
\text { Toronto, Ontario, } \\
\text { Canada }\end{array}$ & $\begin{array}{l}\text { Data collection, drafted } \\
\text { electronic data collection } \\
\text { forms }\end{array}$ \\
\hline $\begin{array}{l}\text { Minal S. Jain, PT, } \\
\text { DSc }\end{array}$ & $\begin{array}{l}\text { National Institutes of } \\
\text { Health, Bethesda, MD }\end{array}$ & $\begin{array}{l}\text { Data collection and } \\
\text { analysis, provided input } \\
\text { on study design, revision } \\
\text { of the manuscript }\end{array}$ \\
\hline $\begin{array}{l}\text { Michael W. } \\
\text { Lawlor, MD, PhD }\end{array}$ & $\begin{array}{l}\text { Medical College of } \\
\text { Wisconsin, Milwaukee }\end{array}$ & $\begin{array}{l}\text { Data collection, revision } \\
\text { of the manuscript }\end{array}$ \\
\hline $\begin{array}{l}\text { Oscar H. Mayer, } \\
\text { MD }\end{array}$ & $\begin{array}{l}\text { Children's Hospital of } \\
\text { Philadelphia, PA }\end{array}$ & $\begin{array}{l}\text { Data collection, revision } \\
\text { of the manuscript }\end{array}$ \\
\hline $\begin{array}{l}\text { Leslie Nelson, } \\
\text { PT, PhD }\end{array}$ & $\begin{array}{l}\text { UT Southwestern } \\
\text { Medical Center, Dallas, } \\
\text { TX }\end{array}$ & $\begin{array}{l}\text { Data collection and } \\
\text { analysis }\end{array}$ \\
\hline $\begin{array}{l}\text { Nicole } \\
\text { Sultanum, MSc }\end{array}$ & $\begin{array}{l}\text { University of Toronto; } \\
\text { Hospital for Sick } \\
\text { Children, Toronto, } \\
\text { Ontario, Canada }\end{array}$ & $\begin{array}{l}\text { Data collection, drafted } \\
\text { electronic data collection } \\
\text { forms }\end{array}$ \\
\hline Faiza Syed, RRT & $\begin{array}{l}\text { Hospital for Sick } \\
\text { Children, Toronto, } \\
\text { Ontario, Canada }\end{array}$ & Data collection \\
\hline Tuyen Tran, RRT & $\begin{array}{l}\text { Hospital for Sick } \\
\text { Children, Toronto, } \\
\text { Ontario, Canada }\end{array}$ & Data collection \\
\hline
\end{tabular}

Appendix (continued)

\begin{tabular}{lll}
\hline Name & Location & Contribution \\
\hline $\begin{array}{l}\text { Ching H. Wang, } \\
\text { MD }\end{array}$ & $\begin{array}{l}\text { Driscoll Children's } \\
\text { Hospital, Texas A\&M } \\
\text { University, Corpus } \\
\text { Christi }\end{array}$ & Data collection \\
\hline $\begin{array}{l}\text { James J. Dowling, } \\
\text { MD, PhD }\end{array}$ & $\begin{array}{l}\text { Hospital for Sick } \\
\text { Children, Toronto, } \\
\text { Ontario, Canada }\end{array}$ & $\begin{array}{l}\text { Data collection and } \\
\text { analysis, provided input } \\
\text { on study design, drafting } \\
\text { and revision of the } \\
\text { manuscript }\end{array}$ \\
& &
\end{tabular}

\section{References}

1. North KN, Laing NG, Wallgren-Pettersson C. Nemaline myopathy: current concepts the ENMC International Consortium and Nemaline Myopathy. J Med Genet 1997; 34:705-713.

2. Pelin K, Hilpela P, Donner K, et al. Mutations in the nebulin gene associated with autosomal recessive nemaline myopathy. Proc Natl Acad Sci USA 1999;96: 2305-2310.

3. Wallgren-Pettersson C, Pelin K, Nowak KJ, et al. Genotype-phenotype correlations in nemaline myopathy caused by mutations in the genes for nebulin and skeletal muscle alpha-actin. Neuromuscul Disord 2004;14:461-470.

4. Nowak KJ, Wattanasirichaigoon D, Goebel HH, et al. Mutations in the skeletal muscle alpha-actin gene in patients with actin myopathy and nemaline myopathy. Nat Genet 1999;23:208-212.

5. Agrawal PB, Strickland CD, Midgett C, et al. Heterogeneity of nemaline myopathy cases with skeletal muscle alpha-actin gene mutations. Ann Neurol 2004;56:86-96.

6. Donner $\mathrm{K}$, Ollikainen $\mathrm{M}$, Ridanpaa $\mathrm{M}$, et al. Mutations in the beta-tropomyosin (TPM2) gene: a rare cause of nemaline myopathy. Neuromuscul Disord 2002;12. 151-158

7. Laing NG, Wilton SD, Akkari PA, et al. A mutation in the alpha tropomyosin gene TPM3 associated with autosomal dominant nemaline myopathy NEM1. Nat Genet $1995 ; 10: 249$.

8. Wattanasirichaigoon D, Swoboda KJ, Takada F, et al. Mutations of the slow muscle alpha-tropomyosin gene, TPM3, are a rare cause of nemaline myopathy. Neurology 2002;59:613-617.

9. Sambuughin N, Yau KS, Olive M, et al. Dominant mutations in KBTBD13, a member of the BTB/Kelch family, cause nemaline myopathy with cores. Am J Hum Genet 2010;87:842-847.

10. Agrawal PB, Greenleaf RS, Tomczak KK, et al. Nemaline myopathy with minicores caused by mutation of the CFL2 gene encoding the skeletal muscle actin-binding protein, cofilin-2. Am J Hum Genet 2007;80:162-167.

11. Ravenscroft G, Miyatake S, Lehtokari VL, et al. Mutations in KLHL40 are a frequent cause of severe autosomal-recessive nemaline myopathy. Am J Hum Genet 2013;93: $6-18$.

12. Gupta VA, Ravenscroft G, Shaheen R, et al. Identification of KLHL41 mutations implicates BTB-kelch-mediated ubiquitination as an alternate pathway to myofibrillar disruption in nemaline myopathy. Am J Hum Genet 2013;93:1108-1117.

13. Yuen M, Sandaradura SA, Dowling JJ, et al. Leiomodin-3 dysfunction results in thin filament disorganization and nemaline myopathy. J Clin Invest 2014;124:4693-4708.

14. Miyatake S, Mitsuhashi S, Hayashi YK, et al. Biallelic mutations in MYPN, encoding myopalladin, are associated with childhood-onset, slowly progressive nemaline myopathy. Am J Hum Genet 2017;100:169-178.

15. Johnston JJ, Kelley RI, Crawford TO, et al. A novel nemaline myopathy in the Amish caused by a mutation in troponin T1. Am J Hum Genet 2000;67:814-821.

16. Abdulhaq UN, Daana M, Dor T, et al. Nemaline body myopathy caused by a novel mutation in troponin T1 (TNNT1). Muscle Nerve 2016;53:564-569.

17. Sandaradura SA, Bournazos A, Mallawaarachchi A, et al. Nemaline myopathy and distal arthrogryposis associated with an autosomal recessive TNNT3 splice variant. Hum Mutat 2018;39:383-388.

18. Ryan MM, Schnell C, Strickland CD, et al. Nemaline myopathy: a clinical study of 143 cases. Ann Neurol 2001;50:312-320.

19. Yin X, Pu CQ, Wang Q, Liu JX, Mao YL. Clinical and pathological features of patients with nemaline myopathy. Mol Med Rep 2014;10:175-182.

20. Maggi L, Scoto M, Cirak S, et al. Congenital myopathies: clinical features and frequency of individual subtypes diagnosed over a 5-year period in the United Kingdom. Neuromuscul Disord 2013;23:195-205.

21. Colombo I, Scoto M, Manzur AY, et al. Congenital myopathies: natural history of a large pediatric cohort. Neurology 2015;84:28-35.

22. North KN, Ryan MM. Nemaline myopathy. In: Adam MP, Ardinger HH, Pagon RA, et al, editors. GeneReviews ${ }^{\circledR}$. Seattle: University of Washington; 1993.

23. Berard C, Payan C, Hodgkinson I, Fermanian J; MFM Collaborative Study Group. A motor function measure for neuromuscular diseases: construction and validation study. Neuromuscul Disord 2005;15:463-470. 
24. Pereira AC, Ribeiro MG, Araujo AP. Timed motor function tests capacity in healthy children. Arch Dis Child 2016;101:147-151.

25. Quanjer PH, Stanojevic S, Cole TJ, et al. Multi-ethnic reference values for spirometry for the 3-95-yr age range: the global lung function 2012 equations. Eur Respir J 2012; 40:1324-1343.

26. Verma R, Chiang J, Qian H, Amin R. Maximal static respiratory and sniff pressures in healthy children: a systematic review and meta-analysis. Ann Am Thorac Soc 2019;16:478-487.

27. Bianchi C, Baiardi P. Cough peak flows: standard values for children and adolescents. Am J Phys Med Rehabil 2008;87:461-467.

28. Thomas-Stonell N, Greenberg J. Three treatment approaches and clinical factors in the reduction of drooling. Dysphagia 1988;3:73-78.

29. Reid SM, Johnson HM, Reddihough DS. The Drooling Impact Scale: a measure of the impact of drooling in children with developmental disabilities. Dev Med Child Neurol 2010;52:e23-28.
30. Hudspeth MP, Holden KR, Crawford TO. The "slurp" test: bedside evaluation of bulbar muscle fatigue. Pediatrics 2006;118:e530-533.

31. Vuillerot C, Payan C, Girardot F, et al. Responsiveness of the motor function measure in neuromuscular diseases. Arch Phys Med Rehabil 2012;93: 2251-2256.e1.

32. Gonorazky HD, Naumenko S, Ramani AK, et al. Expanding the boundaries of RNA sequencing as a diagnostic tool for rare mendelian disease. Am J Hum Genet 2019; 104:1007.

33. Posey JE, O’Donnell-Luria AH, Chong JX, et al. Insights into genetics, human biology and disease gleaned from family based genomic studies. Genet Med 2019;21: 798-812.

34. Cummings BB, Marshall JL, Tukiainen $\mathrm{T}$, et al. Improving genetic diagnosis in mendelian disease with transcriptome sequencing. Sci Transl Med 2017;9: eaal5209. 


\title{
Neurology
}

\author{
A Cross-Sectional Study of Nemaline Myopathy \\ Kimberly Amburgey, Meryl Acker, Samia Saeed, et al. \\ Neurology 2021;96;e1425-e1436 Published Online before print January 4, 2021 \\ DOI 10.1212/WNL.0000000000011458
}

This information is current as of January 4, 2021

Updated Information \&
Services

References

Citations

Subspecialty Collections

Permissions \& Licensing

Reprints including high resolution figures, can be found at: http://n.neurology.org/content/96/10/e1425.full

This article cites 33 articles, 7 of which you can access for free at: http://n.neurology.org/content/96/10/e1425.full\#ref-list-1

This article has been cited by 1 HighWire-hosted articles: http://n.neurology.org/content/96/10/e1425.full\#\#otherarticles

This article, along with others on similar topics, appears in the following collection(s):

Natural history studies (prognosis)

http://n.neurology.org/cgi/collection/natural_history_studies_prognosis

Information about reproducing this article in parts (figures,tables) or in its entirety can be found online at:

http://www.neurology.org/about/about_the_journal\#permissions

Information about ordering reprints can be found online:

http://n.neurology.org/subscribers/advertise

Neurology ${ }^{\circledR}$ is the official journal of the American Academy of Neurology. Published continuously since 1951, it is now a weekly with 48 issues per year. Copyright Copyright ( 2021 The Author(s). Published by Wolters Kluwer Health, Inc. on behalf of the American Academy of Neurology.. All rights reserved. Print ISSN: 0028-3878. Online ISSN: 1526-632X.

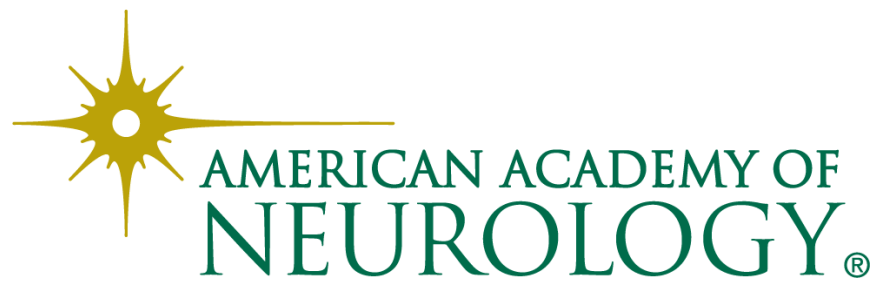

